PART 1

Quranic Netherworlds 
Tommaso Tesei - 9789004301368

Downloaded from Brill.com04/26/2023 01:42:43PM via free access 


\title{
The barzakh and the Intermediate State of the Dead in the Quran
}

\author{
Tommaso Tesei
}

Eschatological ideas are central to Quranic theology. ${ }^{1}$ The expectation that at the end of time God will raise the dead, judge their deeds, and mete out rewards and punishments accordingly is one of the doctrines the Quran most often exhorts its audience to accept. The Quranic discourse is marked by constant admonitions about the Hour $(a l-s \bar{a} c a)$, the proximity of which is highlighted, even though it is not revealed exactly when it will occur. The belief in these final events, which take place in at an unspecified future point in time, raises the question of the interim condition of the dead who are waiting to be resurrected and judged. An answer in the Quran to this theological problem is elusive, as it addresses it on very few occasions. As is often the case, what is not addressed in the Quran is discussed in Muslim exegesis. The exegetes (mufassirūn) developed a complex set of views about this intermediate state, mostly as result of speculation about barzakh, a term that in Q 23:100 is used to describe an obstacle standing behind the dead until the day of resurrection.

However, the present study is not mainly concerned with the mufassirüns' views about the barzakh. It will instead focus on the question of the interim fate of the dead in the Quran in light of late antique theology and imagery about the afterlife. Here, the works of Syriac authors who wrote in the Middle East between the fourth and seventh centuries CE deserve special consideration. Because of their chronological and geographical proximity to both the period and location assumed for the compilation of the Quran these works can be expected to contain elements valuable for a better understanding of

1 This article was written during a period I had the privilege of spending as a guest of Utrecht University (September-October 2012). Many of the ideas developed in the following pages are the results of the many interesting conversations I had with scholars at this friendly and stimulating research environment. Above all, I would like to thank Christian Lange and Simon O'Meara for their comments and useful suggestions; I am also grateful to Gabriel Said Reynolds, Guillaume Dye and Sidney Griffith for their helpful comments on different versions of this article.

(C) Tommaso Tesei, 2016 | DOI 10.1163/9789004301368_003

This is an open access chapter distributed under the terms of the Creative Commons Attribution-

Noncommercial 3.o Unported (CC-BY-NC 3.0) License. 
the Quran. Indeed, as I will suggest in the following pages, the Quranic views and imagery of the intermediate state appear to be closely related to doctrines, beliefs, and tropes widespread among Syriac Christians during Late Antiquity.

\section{The barzakh in Light of the Late Antique Imagery about} the Afterlife

Q 23:99-100: Till, when death comes to one of them, he says, "My Lord, return me; haply I shall do righteousness in that I forsook". Nay, it is but a word he speaks; and there; behind them, is a barrier (barzakh) until the day that they shall be raised up. ${ }^{2}$

These verses from sürat al-mu'minūn form the locus classicus for the question of the intermediate state in the Quran. The mufassirün expended considerable energy speculating on the meaning of these two verses. The term barzakh mentioned in v. 100 is the crux for the commentators, who explain it either as the space between the worlds of the living and the dead or as the time between death and resurrection. ${ }^{3}$ The etymology and meaning of the word in the Quran are uncertain. ${ }^{4}$ The Quranic text suggests that barzakh means a physical obstacle that confines the dead to an unspecified place until the time of their resurrection. Western scholars have, in consequence, understood the barzakh as a barrier that prevents the deceased from returning to the world of the living. The interpretation of barzakh as a barrier is strengthened by the two other occurrences of the word, in Q 25:53 and 55:19, where a barzakh is said to separate the two cosmic seas of sweet and salt waters. Therefore, it seems that the Quran attributes to the barzakh the twofold function of cosmological and eschatological partition.

In vv. 99-100 of sürat al-mu'minün the Quran makes reference to the bar$z a k h$ in connection with a common topos of its eschatological discourse, that of the impossibility of repentance after death. This idea is fully expressed by the motif of the sinner's denied request to be returned to the world in order to make amends for their sins. The same motif occurs in other Quranic passages $(6: 27 ; 7: 53 ; 14: 44 ; 23: 107 ; 32: 12-5 ; 35: 36-7 ; 39: 58 ; 42: 44 ; 63: 10)$, although here the term barzakh is never mentioned. Moreover, in most cases God's refusal to

2 Here and in what follows, the translations of the Quranic passages are those by A.J. Arberry.

3 Western scholarship has produced an extensive literature on the development of the concept of barzakh in the Islamic tradition: see Carra de Vaux, Barzakh; Eklund, Life; Lange, Barzakh;

Zaki, Barzakh.

4 See Jeffery, Foreign vocabulary 77. 
send the dead back seems to take place once the resurrection and judgment have been carried out and sinners have been condemned to punishment in the fire. Only on one other occasion (63:10) does it seem that the scenario of the denied request occurs before the final events. However, Q 23:99-10o represents the only case where the Quran explicitly relates the motif to the intermediate state, as the words ila ayawm yub'athüna, "until the day that they shall be raised up", make it clear that the scene occurs between death and resurrection.

The idea that it is impossible to return from the realm of death to remedy the sins committed during one's lifetime is not limited to the Quranic eschatological discourse. The same concept is expressed in a passage of 4 Ezra (probably composed in the late first century), according to which the souls of condemned sinners are aware of the impossibility of returning to act righteously (VII:80-2). Similarly, the motif of the denied request of sending someone dead back to the world of the living often occurs in late antique exegeses of the famous parable of the rich man and the poor man found in the Gospel of Luke (Lk 16:19-31). ${ }^{5}$ This parable presents the post-mortem states of the two characters as a reversal of their terrestrial ones: the poor man is carried by the angels to "the bosom of Abraham", while the rich man is buried and tormented in Hades. The passage that interests the present study occurs at the end of the parable, when the rich man begs Abraham to send the poor man to warn his family, "so that they will not also come into this place of torment" (v. 28). However, Abraham rejects the request by saying that if the rich man's family does not believe the prophets they will not believe the dead (Lk 16:27-31).

The dynamic described in Luke's parable appears to be recalled by the Quranic passage discussed here: in the first case, a sinner asks whether someone dead can return to the world to prevent others from acting impiously; in the second case, a sinner asks to be returned so he can act righteously. In both cases the request is denied. It is important to observe that the story of the rich man and the poor man is quoted by almost every late antique Christian author who wrote about the afterlife. One should consider the possibility, therefore, that the Quran, like so many other texts from Late Antiquity, included some elements of the parable in the elaboration of its eschatological discourse. This notion is strengthened by the evidence that the author(s) of the Quran was (were) aware of the parable, as some of its elements are included in vv. 46-50 of sürat al-a'răf $(7)$. Indeed, the scene described in Q 7:50, where sinners in hell ask the righteous in paradise to pour water on them, rather closely echoes the unfulfilled request of being refreshed that the rich man addresses to the poor

5 On the eschatology of this parable, see Kreitzer, Luke 16:19-31; Lehtipuu, Afterlife imagery; Osei-Bonsu, Intermediate state. 
in Lk 16:24-6. Moreover, the veil (hijäb) that in Q 7:46 is said to lie between sinners and the righteous parallels the great chasm that in Lk 16:26 separates the rich man from the poor.

As in the case of many Quranic passages that deal with biblical material, verses 99-100 of sürat al-mu'minūn appear to be more closely related to late antique traditions and exegeses about biblical texts than to the Scripture itself. In fact, the connection with Lk 16:27-31 becomes very close when considering a homily that Narsai (d. ca. 502) wrote around the parable. Worthy of particular consideration are the following words that the East Syrian Church Father and poet adds to Abraham's negative answer to send the poor man back to the rich man's family:

A strong barrier (syāga $)$ rises in front of the faces of the dead, and none among them can break it because of its solidity. Insurmountable is the wall ( $\check{s} u r \bar{a})$ which death built up in front of the faces of the dead, why do you ask for something whose accomplishment cannot be allowed? 6

Narsai's reference to obstacles behind which the dead are confined shows a rather precise correspondence with the Quranic barzakh. The parallel is particularly striking because in both cases the allusion to the eschatological barrier is inserted within the narrative of a denied request by someone dead to return to the world of the living. Of course, with this I do not mean that Narsai's homily acts as a direct source for the Quranic passage, but rather that verses 99-100 of al-mu'minün reflect some theological trends and cultural concepts that were widespread in Late Antiquity.

From this perspective, it might be observed that the notion of a barrier preventing the dead from returning to this world is consistent with another common late antique representation of the netherworld, that of it being a place from which it is impossible to escape. This idea was widespread among the Syriac speaking communities of the Middle East; indeed, Syriac authors consistently describe Sheol, the realm of death, as a subterranean place with gates ${ }^{7}$ and walls to ensure the dead are confined. ${ }^{8}$ For instance, in the Nisibene

6 Narsai, Cinq homélies 55 (Syriac text: right column; French translation: left column).

7 The image of the gates of Sheol has its roots in the biblical descriptions of the realm of death. This occurs in several places in the Hebrew Bible (Isa. 38:10; Ps. 9:14, 107:18; Job 38:17), in postbiblical literature (Eccl. 51:9; Wisdom of Solomon 16:13; Ps. of Solomon 16:2; 3 Mac. 5:51), in the scripts of Qumran (1QH $\mathrm{QIV}: 207 ; 4 \mathrm{Q} 184: 10)$ and in the New Testament (Matt. 16:18).

8 On the theme of Sheol in Syriac literature, see Kollamparampil, Theme of Sheol. 
hymns (10:12), Ephrem (d. 373) states that the sinners are confined beyond a "wall of water". In the same way, in a homily by Jacob of Serugh (d. 521), Sheol is defined as "high-walled" (79:353)..$^{9}$ The images of the afterlife that Narsai produces in the above verses are modeled on the same pattern, as the rich man is said to be imprisoned in Sheol. ${ }^{10}$ Other references to barriers or walls are often found in the numerous texts written as part of the tradition of Christ's descent to, and subsequent ascension from, the netherworld, according to which Jesus visited the realm of the dead during the period between his crucifixion and resurrection. ${ }^{11}$ The author of the work known as the Teaching of Addai the Apostle (fifth century) asserts that Christ "went down to the house of the dead, broke through the barrier (syāga $)$ which had never been broken through before, and gave life to the dead by being himself killed".12 Jacob of Serugh similarly speaks of the "hero", that is, Jesus, who "has the strength to enter Sheol and to tear down its walls", ${ }^{13}$ and of "the Slaughtered One who crushed the high fortifications" (hesnē rāmēe). ${ }^{14}$ Finally, Narsai asserts that

he [i.e., Christ] descended according to (his) nature that begets passions and dwelt in Sheol

and brought up with him a catch of men to new life.

He broke (through) the wall which death had built before the dead, and opened a way for mortality to vitality. ${ }^{15}$

The idea of Christ forcing a way through the boundaries of Sheol clearly demonstrates his ability to perform the miracle of resurrection and to escape the realm of death. The breach he opens up in the eschatological barrier also foreshadows the definitive collapse of Sheol, expected to take place on the Day of Judgment. Indeed, Jacob of Serugh asserts that on that day the general

9 Here and in what follows the homilies by Jacob of Serugh are classified according to P. Bedjan's ordering.

$10 \quad$ Narsai, Cinq homélies 50-1.

11 The motif of the breach that Jesus opens up in the eschatological barrier/walls parallels the more common image of Christ's breaking the bars/gates of Sheol when rising from among the dead. On this tradition, see Brock, The gates/bars.

12 Teaching of Addai 17.

13 Jacob of Serugh, Homilies on Elijah 109 (tr. 198).

14 Jacob of Serugh, Homilies on the Resurrection 57 (tr. 56 ).

15 Narsai, Metrical homilies $154-5$. It is worth remarking on the proximity between the vocabulary of the Quranic verses and that used by Narsai in the quoted passage from the homily on the parable in Luke - with the difference, of course, that Christ here is credited with the ability to overcome the eschatological barrier. 
resurrection will produce the collapse of the walls of Sheol and allow the people imprisoned there to escape (67:311-2; cf. 54:20, 39-40).

The texts quoted above lay out the theological and cultural contexts for Q 23:99-100, and constitute a significant example of the close relationship between the Arabic book and its cultural environment. It might also be observed that the Quran ostensibly conceives of the unspecified place beyond the barzakh in roughly the same manner as the Syriac authors envisage Sheol. For example, according to their eschatological doctrine, Sheol is the interim abode where the dead are confined while waiting to be brought back to life, ${ }^{16}$ and this belief is echoed in the Quranic sentence that states that "behind them is a barrier until the day that they shall be raised up", which suggests that the place beyond the barzakh is where the dead are held captive until the day of resurrection.

A deeper examination of the last words of this sentence, "until the day that they shall be raised up" (ilä yawm yub'athüna), further suggests this. This is a fairly common expression within the Quranic corpus, occurring a total of six times (Q 7:14; 7:167; 15:36; 23:100; 37:144; 38:79; cf. Q 30:56). In addition to Q 23:100, the one example that is of particular interest for the present study is found in Jonah's story in Q 37:143-4, where is stated that: "Now had he [Jonah] not been of those that glorify God, [144] he would have tarried in its belly until the day they shall be raised". Thus, the Quran confers an eschatological dimension on the belly of the fish in which Jonah is confined and posits an internal parallelism between this belly and the place beyond the barzakh. As such, both spaces are conceived of as sites of temporary confinement until the day of the final resurrection.

This reflects a common association of the belly of Jonah's fish with Sheol in the Syriac literature. For example, on the basis of Matt. 12:40, Syriac authors often described Jonah's captivity and exit from the belly of the fish as a foreshadowing of Christ's visit to and rising from Sheol. ${ }^{17}$ Within this literary parallel, the belly of the fish comes to be associated with the eschatological place in which the dead are kept as prisoners until their resurrection. The fact that

16 See Daley, Hope 72-6, 171-6. A similar idea is also found in the works of some early "Western" Christian authors, such as Tertullian (De Anima 55-8), Hippolytus (Against Plato 1) and Origen (De Principiis 4:3), according to whom the souls of the dead wait to be resurrected in Hades.

17 See for example, Ephrem, Commentary on the Diatessaron 11:3; idem, Hymns on Virginity 42:12-6; idem, Homily on our Lord 2:1; Jacob of Serugh, Homily on Jonah (mēmrā 122 in Bedjan's ordering: Homiliae selectae iv, 368-49o); Narsai, Homily on Jonah (mēmrā 8 in the first volume of Mingana's edition: Narsai doctoris Syri homilice et carmina i, 134-49). 
the Quran operates with this same association confirms that the early community of believers was familiar with theological views about Sheol widespread among Syriac Christians, which are also at play in Q 23:99-100. ${ }^{18}$ The Quran never explicitly mentions the realm of death, and instead focuses its attention mostly on the place of final punishment, Gehenna (jahannam). Nevertheless, the above examples suggest that the Quranic eschatological discourse shares tropes and literary images used by several Syriac authors to describe the condition of the dead in Sheol.

Muslim exegetes took Q 23:99-100 as evidence for the existence of an intermediate state between death and resurrection. In the Islamic tradition this came to be designated through the term barzakh, though in the Quran the latter is more likely to designate an eschatological boundary of sorts that parallels the image of the barrier/walls of Sheol. The scene in Q 23:99-100 presenting a sinner who begs God to be returned so he can act righteously was taken by the mufassirün as implying that the dead beyond the barzakh are in a state of consciousness similar to that experienced during life on earth. However, as Reynolds observes, "the language here is strongly homiletic, the point being that humans must not postpone their repentance, and the following section (vv. 101-6) makes it clear that judgment and retribution comes on that Day [of Judgment]". ${ }^{19}$ In fact, the Quran hints several times that men will not have any conscious record about the events they undergo between death and resurrection.

Q 10:45 affirms that on the Day of Judgment the dead will feel "as if they had not tarried but an hour of the day", and similar statements occur in Q 17:52, 30:55, and 46:35. The same topos about the impossibility of correctly perceiving the length of "death time" occurs, in a more elaborated way, in other Quranic passages. For example, in the account of the man and his donkey in Q 2:259, God "made him die a hundred years", and after raising him up He questions

18 It might be observed that the association between the belly of the fish and Sheol is already found in Jonah 2:2, which speaks of "the belly of Sheol". However, as is known, the interpretation of Sheol as an interim abode of the dead is not found in the Hebrew Bible. The eschatological dimension the Quran attributes to the belly of the fish, marked by the sentence ilā yawm yub'athūna, appears to be primarily influenced by Syriac Christian doctrines about Sheol.

19 Reynolds, Qur'ān 157. 
him: “'How long hast thou tarried?' He said, 'I have tarried a day, or part of a day.' Said He, 'Nay; thou hast tarried a hundred years [...]'”. In Q 23:112-4, God asks the sinners in the same way about the length of time they spent in the grave. When they reply "We have tarried a day, or part of a day; ask the numberers!" God mocks their answer by stating that "You have tarried but a little, did you know". In Q 20:103-4, at the Resurrection sinners discuss the length of the time they spent in the grave and "whisper one to another, 'You have tarried only ten nights' ". A quite identical situation occurs in Q 18, in the story of the Companions of the Cave (vv. 9-26), whose sleep and awakening clearly functions as a metaphor for death and resurrection. ${ }^{20}$ As God affirms in Q 18:19: "We raised them up again that they might question one another. One of them said, 'How long have you tarried?' They said, 'We have tarried a day, or part of a day. They said, 'Your Lord knows very well how long you have tarried [...]" (cf. Q 18:12).

This survey of passages makes it clear that according to Quranic eschatology people will experience nothing during the time which elapses between their death and resurrection. It has been suggested that the Quranic idea that the dead fall completely unconscious until the Day of Judgment is closely connected to the doctrine of the sleep of souls which was widespread among Syriac Christians. ${ }^{21}$ This belief is first attested in the writings of Aphrahat (d. 345) and Ephrem, ${ }^{22}$ occurs later in those by Jacob of Serugh, ${ }^{23} \mathrm{Narsai}^{24}$ and Babai the Great (d. 628), and, at the end of the second/eighth century (in 786-7), was canonized in a synod presided over by the Catholicos Timothy I (d. 823). According to this doctrine, after death and until the resurrection the soul lies in Sheol in a sleep-like state, during which it is deprived of its sense faculties. ${ }^{25}$ Aphrahat affirms that during this period the dead lose their memory; they will recover it only after the resurrection on the Day of Judgment. Furthermore, the dead do not receive any preliminary reward or punishment. Indeed,

20 As Reynolds observes, "[ $\mathrm{t}]$ he youths are said to be asleep in the cave (Q 18:18), yet the Quran strongly suggests (see e.g. Q 18:11-2, 21) that in fact they are dead. The entire episode points to God seizing souls at the body's death, then reuniting soul and body on the Day of Judgment, that is, to the resurrection of the body", Ibid. Andrae, Origines 165-7; idem, Mohammed 89-90; O'Shaughnessy, Muhammad's thoughts 69-70.

22 See ibid., 74-5; Gavin, Sleep 104-7.

23 See Guinan, Where are the dead? 542.

24 See Krüger, Sommeil 193-210; Gignoux, Doctrines eschatologiques 331-4; Daley, Hope 174; Samellas, Death $5^{6-7}$.

See Daley, Hope 73 . 
Aphrahat unequivocally states that "as yet no one has received his reward. For the righteous have not inherited the Kingdom, nor have the wicked gone into torment". ${ }^{26}$ Ephrem also maintains this view and stresses the fact that reward (or punishment) cannot be experienced before the resurrection because of the soul's inability to act without the body. In his Hymns on paradise, Ephrem reasons that

and the soul cannot * enter there [paradise] alone

for in such state it is in everything * deficient-

in sensation and consciousness; * but on the day of Resurrection

the body, with all its senses, * will enter in as well, once it has been made perfect (8:9). ${ }^{27}$

Because of the important role he attributes to the body, without which "it [the soul] lacks true existence" (8:4), ${ }^{28}$ Ephrem dismisses the possibility, expressed by Aphrahat, that the soul in Sheol might dream about its future destiny. ${ }^{29} \mathrm{~A}$ similar position is held by Narsai, who argues that "if, during bodily sleep, it [the soul] can do nothing, how can it now, when it [the body] is plunged in the sleep of death?"30 It is doubtless in accordance with this view that in his homily on Luke's parable Narsai stresses the metaphorical value of the story, whose literal interpretation would instead suggest the soul's activity in Sheol. ${ }^{31}$ Similar concepts about the soul's dormant state are expressed by the East Syrian theologian Babai the Great, who in the Commentary on Evagrius states that "after its [the soul's] separation from the body all its activities are in a kind of sleep". This is proved, he continues, by the fact that "our Lord and his apostles call the death sleep and slumber" and by "the miracle in the city of Ephesus" (that is, the story of the Seven Sleepers). ${ }^{32}$ Babai professes the same creed in his Book of union, where he affirms:

26 Passage reported ibid.

27 Ephrem, Hymns on paradise $133-4$.

28 Ibid., 133.

29 Ibid., 74.

30 Narsai, Narsai homilice ii, 253. Translations can be found in O'Shaughnessy, Muhammad's thoughts 70; Krüger, Sommeil 202.

$31 \quad$ Narsai, Cinq homélies 47-51.

32 Babai, Commentary on Evagrius 30/31. Cf. Braun, Mose Bar Kepha 145; Gavin, Sleep 107; Andrae, Origines 166-7; idem, Mohammed 89-90. 
Without the body, once being separated from it, [the soul] exists and does not exist. It exists, as it keeps its nature, its vitality and its reason. It does not exist, as it does not perform the properties of its nature: it does not remember nor think without its companion [the body], but its state is like [total] stillness and the deep sleep, as it is written [cf. Job 3:13]. ${ }^{33}$

In sum, the Quranic belief that, in Tor Andrae's words, "the soul sinks into complete unconsciousness after death, so that the Day of Judgment seems to follow immediately after death", ${ }^{34}$ is likely to have been inspired by much the same theological concepts taught by the Syriac authors. From this perspective, it is extremely significant that in certain passages the Quran presents this unconscious, intermediate state as a sleep-like one. Such is the case, for instance, in the account of the Companions of the Cave, which also offers a perfect example of the communion of cultural views and literary motifs between the Quran and various Syriac authors. As is known, this account is based on the same story of the Sleepers of Ephesus that, in the late sixth/early seventh century, Babai presented as a proof of his eschatological doctrine. ${ }^{35}$ The association between death and sleep is also implied in Q $36: 52$, where it is expressed by the complaint of the sinners: "Alas for us! Who roused us out of our sleeping place?" It is worth noting that the word marqad, "sleeping place", is related by its root to ruqūd, "asleep", which in Q 18:18 designates the Companions: "Thou wouldst have thought them awake, as they lay sleeping" (wa-tahsabuhum ayqāzan wa-hum ruqüdun). It is significant that the root r.q.d., semantically related to the idea of sleep, occurs only twice in the Quran (in the two cases mentioned above), yet it is always in connection with death and the hereafter. This suggests that the two terms marqad and ruqūd specifically designate a kind of "eschatological rest".

At the same time, the Quran also compares death to the "common sleep" that people experience on a daily basis. This seems to be the case in the cryptic statement found in Q 39:42 (cf. Q 6:60), "God takes the souls at the time of their death (hina mawtihā), and [He takes] that which has not died, in its sleep ( $f i$ manāmiha $)$; He withholds that against which He has decreed death, but sets loose the other until a stated term". This obscure passage appears to indicate that sleep is a death-like state; sleepers resemble the dead since their souls

33 Babai, Liber de unione i, 297. See also ibid., i, 275 .

34 Andrae, Mohammed 89.

35 On the relationship between the Quranic account of the Companions of the Cave and the legend of the Sleepers of Ephesus, see the insightful study by Griffith, 'Companions'. See also Reynolds, Qur'ān $167-85$. 
enter into a state similar to that which they will experience at the moment of death. However, unlike the souls of the dead, which will be raised only on the Day of Resurrection, the ordinary sleeper's soul is sent back when he awakens - that is, of course, until the time of his death. This parallel between death and "common sleep" finds a fairly close correspondence in the poetical language used by Ephrem, who in the Nisibene hymns (7:15) affirms that: "The one who lies down to sleep resembles the departed and death resembles a dream, and the resurrection the morning". ${ }^{36}$

As is the case in the doctrine taught by the Syriac authors, that expressed in the Quran seems to imply that the soul will be rewarded or punished only after the final Judgment. It is plausible that, like the Syriac theologians, the author(s) of the Quran conceived of the restoration of the body as a fundamental part of experiencing the final sentence, and the emphasis the Quran continually puts on the physical resurrection which will occur on the Day of Judgment seems to point in this direction. In fact, it might be observed that references to the unconsciousness of the dead often occur in passages that profess or aim to demonstrate the reality of the restoration of the body. For instance, the statement in Q 17:52, mentioned above, "you will think you have tarried but a little", is preceded by three verses in which the Quran argues against those who are skeptical of physical resurrection:

They say, 'What, when we are bones and broken bits, shall we really be raised up again in a new creation?' [50] Say: 'Let you be stones, or iron, [51] or some creation yet more monstrous in your minds!' Then they will say, 'Who will bring us back?' Say: 'He who originated you the first time.' [...].

The scene in Q 23:112-4, where God questions the sinners about the length of their death, is similarly followed in v. 115 by the statement: "What, did you think that We created you only for sport, and that you would not be returned to Us?" The same intention to prove the resurrection of the body underlies the story of the man and his donkey in Q 2:259. Here, after questioning the man about the length of time he has been dead and demonstrating his altered perception of time, God tells him: "... We would make thee a sign for the people. And look at the bones; how We shall set them up, and then clothe them with flesh". In much the same way, in the account of the Companions of the Cave, which more than any other points to the Quran's awareness of the Syriac doctrine of the sleep of souls, the clear aim is to demonstrate God's ability to resurrect the

36 Quoted by Buchan, "Blessed is He" 296. 
dead: "And even so We made them stumble upon them, that they might know that God's promise is true, and that the Hour-there is no doubt of it [...]" (Q 18:21).

In these passages the Quran's eschatological discourse is particularly close to that formulated by Babai, in whose ideas the belief in the soul's sleep is intimately connected to the strong affirmation of the physical resurrection of the body on the Day of Judgment. ${ }^{37}$ Babai sets his creed in opposition to that of Henana of Adiabene (d. 610), whom he polemically accuses of professing Origenist doctrines and of denying "not only the resurrection of Our Lord's body, but also the general resurrection of the body of all men". ${ }^{38}$ Polemics over this subject did not end with Babai but continued for years after; indeed, when the doctrine of the sleep of souls was canonized at the synod of $786-787$, Timothy I labeled different creeds as Origenist. ${ }^{39}$ In light of these considerations, it is intriguing that the Quran inserts the motif of post-mortem oblivion in passages that specifically contest the deniers of physical resurrection. In fact, it appears that not only does the Quran refer to a concept very similar to that of the sleep of souls taught by the East Syrian theologians, but it also uses it towards roughly the same theological and polemical purposes, namely as an answer to those who deny the reality of physical resurrection. It is also significant that both Babai and the author(s) of the Quran adduce the example of the miraculous sleep of the Youths of Ephesus to corroborate their theological discourses. In fact, Babai's reference to the miracle of Ephesus does not appear to be fortuitous; as Sidney Griffith observes, "the Syriac version/epitome of the Ecclesiastical History of Zacharias of Mytilene [composed around 569] mentions as an occasion of the miracle [of the Sleepers of Ephesus], controversies

37 Babai, Liber de unione 108-9, 183, 197-8.

38 Ibid., 195. Babai is here challenging the Origenist doctrine that the resurrected body will be spherical and ethereal. In fact, in the course of his polemic, he quotes Rom. 8:11 and thunders: "Behold! He said that the body will live, not a sphere, cursed Origenists and Henanists!" Babai then strongly affirms the identity of the actual and raised body, which will be restored to new creation (ibid., 183). His discussion here closely parallels that found in the Replies of Barsanuphius and John (c. 520-540), where Barsanuphius contests the Origenist doctrine of the spherical body and, quoting Ez. 37:3-10, explains that at the moment of resurrection "[bone is gathered] upon bone, joint upon joint, and veins and flesh nerves" (Letter 607, in Barsanuphius, Letters 191). It might be observed that the Quran presents a similar understanding of resurrection, apparently conceived as a restoration of the dead body. For example, the statement in Q 2:259 "We shall set them [the bones] up, and then clothe them with flesh" strongly points in this direction.

Timothy I, Epistulae i, 42-5. See also Constas, To sleep 110-1. 
over the fate of the human body after death sparked by works of Origen". ${ }^{40}$ Thus, the story fits the strong anti-Origenist tones that characterize Babai's Commentary on Evagrius.

What is astonishing is that the Quran refers to the same miracle with much the same theological purpose: to illustrate the post-mortem condition of the dead, marked here as elsewhere by complete oblivion, and to affirm the final resurrection of the body. It is difficult to avoid the impression that in this passage and the others the Quran is not simply referring to a local Arabian context, but rather is participating in a heated theological discussion about the reality of bodily resurrection, which had been challenged by the diffusion of Origenist theories among Middle Eastern Christians in the sixth and seventh centuries. Of course, this view jars with the traditional accounts about the life of Muhammad, according to which the polemic about the resurrection of the body is addressed to Meccan idolaters and not Christians holding Origenist doctrines. ${ }^{41}$ However, recent scholarship has questioned what the religion professed by those people that Muslim tradition portrays as pagan idolaters actually was. Gerald Hawting has convincingly argued that the Quran's invectives against mushrikūn are best explained as polemical discourses addressed against "soft" monotheists. ${ }^{42}$ As for the passages examined here, the impression is that the Quranic affirmation of physical resurrection and its polemic against those who deny it strictly follows the "theological lines" of the discussion that at that very same period was taking place amongst Syriac Christians. If not directly addressing Origenist theories, the Quran's invectives seem at least to adopt the same argument used by the Syriac Christians in the framework of the anti-Origenist polemic. ${ }^{43}$

Similarly, the Quranic motif of the loss of memory suffered by the deceased during the interim state seems to have been inspired by images and concepts very close to those expressed by the Syriac authors. Beliefs similar to that of the sleep of souls are known to have circulated among Arab Christians by the middle of the third century. In his Dialogue with Heraclides, Origen (d. 254) reports a theological discussion he held with a bishop charged with heresy

$40 \quad$ Griffith, 'Companions' 132, n. 37.

41 This view is maintained by most Western scholarship. See, for example, Bell, Origin 87; Abdel Haleem, Introduction 56 .

42 Hawting, Idea. Further significant evidence has recently been adduced by Crone, Religion. I borrow the expression "soft monotheists" from Donner, Muhammad 245.

43 From this perspective, it is worth remarking that sixth century Christian polemicists accuse Origenists of holding to the teachings of the pagans. Cf. Cyril of Scythopolis, Vita Sabae 36 . 
in the Roman province of Arabia (roughly corresponding to modern Jordan) around 244/248 CE. During the debate, Origen affirms, he heard "that some persons here and in the surrounding regions think that the soul, after its deliverance from this life, no longer perceives anything but lies in the tomb in the body" (10:19-20). ${ }^{44}$ A century later, in his Historia ecclesiastica, Eusebius (d. 339) mentions this debate and avers that Origen fought a heresy "foreign to the truth" that had arisen in "Arabia" and whose proponents pretended "that during the present time the human soul dies and perishes with the body, but that at the time of the resurrection they will be renewed together" (VI:37). ${ }^{45}$

Eusebius' reference to the belief in the mortality of the soul raises the question of which creed the Arab Christians professed. In fact, as it is presented by Origen in his Dialogue, the heretical doctrine seems to be very close to the teaching about the sleep of souls that roughly a century later Aphrahat and Ephrem embraced in their works, both of whom professed the post-mortem inactivity of the soul and its final reunion with the body. However, according to Eusebius, the Arab Christians believed in the death of the soul, which appears to be a significant difference to the doctrine taught by the Syriac authors, who affirm not the soul's death but its temporary inactivity. A century after Eusebius, Augustine (d. 430) maintains that the belief in the mortality of the soul is a characteristic of the heretical doctrine of the Arabici. ${ }^{46}$ As Refoulé observes,

Origen's opponents claimed that the soul was deprived of sensitivity after death. Did they consider it as really dead or just as asleep? The two concepts are similar and it is not easy to distinguish between them. ${ }^{47}$

Gavin dismisses the possibility of distinguishing between the two doctrines. According to him "both theories, if indeed there be two, are attempted explanations of the phenomena of death, and the relation of the body and soul to each other". ${ }^{48}$ However, Refoulé convincingly argues that the doctrine attacked by Origen cannot coincide with that of the soul's sleep widespread among Syriac

44 Origen, Dialogue with Heraclides 65.

45 Eusebius, Historia i, 279.

46 Augustine, De haeresibus no. 83.

47 Refoulé, Immortalité 30.

48 Gavin, Sleep 115. Gavin observes that Eusebius' statement is marked by a strongly polemical tone and does not necessarily give a complete picture of the doctrine he attacks. Nevertheless, it might be observed that Gavin's discussion is somewhat undermined by the fact that, at the time he was writing, the text of Origen's Dialogue with Heraclides had not yet been recovered and made available to scholars (the text was first edited by Schérer in 1949). See also Constas, To sleep 111-2. 
Christians. Despite the similarity of the two creeds, he observes, the sources certify that the Syriac theologians were able to make a distinction between them. He concludes that "la conception critiquée par Origène ne peut être celle des hypnopsychiques [i.e., those who profess the doctrine of the sleep of souls] et ne doit donc pas se différencier fondamentalement de celle visée par Eusèbe". 49

Therefore, it seems that the belief professed by the Arab Christians diverged from the one accepted, and later canonized, by the Syriac theologians. While the latter affirmed the soul's post-mortem inactivity, the former conceived of the soul's post-mortem status not as a sleep but as a real death. Although it was continuously opposed, the belief in the soul's mortality must have continued to circulate at least until the end of the second/eighth century CE, when Timothy I rejected it. It is also worth noting that in much the same period the Christian heresiographer John of Damascus (d. 749) classified the Arabs as thnetopsychists [i.e., professing the doctrine of the death of souls] and accused them of believing that the human soul, like that of beasts, is destroyed at death along with the body. ${ }^{50}$ Another possible piece of evidence for the persistence of the belief in the death of the soul occurs in the ninth-century (?) East Syrian Chronicle of Seert, according to which, around the year 580 , the Fathers assembled to discuss the heresy of "those who say that when the man dies, his soul (nafsuhu) dies with him and it rises as the body does". Moreover, the author reports that "Origen had [already] disputed with them about this point and contested it. However, he produced something [even] more abominable than that, namely his affirmation that the spirit (rüh) after leaving the body enters another body". ${ }^{1}$

Such continuing polemic over the centuries suggests that belief in the mortality of the soul was fairly widespread among Arab Christians. In fact, this very doctrine may be alluded to in some Quranic passages, as several references to the death of the soul occur in the obscure verse Q 39:42 (see above). Moreover, Q 3:145 affirms that "it is not given to any soul to die (mā kāna li-nafsin an tamüta), save by leave of God, at an appointed time", while in v. 185 of the same surah it is stated that "every soul shall taste of death" (kullu nafsin dhäiqatu l-mawti), an assertion that is repeated twice more in the Quran (21:35; 29:57). Finally, in Q 31:34 it is observed that "no soul knows in what land it shall die" (wa-mā tadrì nafsun bi-ayyi arḍin tamūtu).

\footnotetext{
49 Refoulé, Immortalité 30.

5o John of Damascus, De haeresibus no. 90.

$5^{1} \quad$ Histoire nestorienne 99 (tr. 191).
} 
It is difficult to establish whether these references to the mortality of the soul are meant to be taken literally or are just tropes for man's death, seeing that the term nafs could be understood as designating either the soul or the individual as a whole. ${ }^{52}$ However, the possibility that these passages refer to the belief in the soul's mortality gains weight when the cultural context of Late Antiquity and the belief that pre-Islamic Arab Christians are accused to have professed are taken into account. This would also be consistent with the presence in the Quran of ideas related to the doctrine of the sleep of souls, as both creeds are based on the same theological assumptions of the post-mortem soul's inactivity and its eventual reunion with the body. However, it must be admitted that this reading is as speculative as it is attractive, given the paucity of evidence enabling us to correctly understand the belief in the death of souls, the diffusion of which among Arab Christians is certified only by sources which are external (and ostensibly hostile) to that religious community. At the same time, despite the lack of documentation to support this view, it would seem plausible that the Quran reflect beliefs and concepts widespread among not only Syriac, but also Arab Christians.

The picture of Quranic eschatology that has emerged so far can be summarized as follows: at death the soul becomes completely unconscious, as in a dreamless sleep; the soul regains consciousness after being reunited with the body on the Day of Judgment; once resurrected, both sinners and the righteous experience the consequences of the acts they committed during their lifetime. As noted above, this eschatology closely parallels the doctrines taught by Syriac theologians and perhaps also certain beliefs widespread among Arab Christians. Unfortunately, the coherence of this picture is broken when other Quranic passages are taken into account. For instance, Q 3:169 affirms: "Count not those who were slain in God's way as dead, but rather living with their Lord (bal ahyä un 'inda rabbihim), by Him provided". A similar statement is found in Q 2:154: "And say not of those slain in God's way, 'They are dead'; rather they are living (bal ahyäun), but you are not aware". Thus, while in general the Quran teaches that retribution will come only on the Day of Judgment, these two verses suggest a different fate to be envisaged for "those who are killed in God's way". While elsewhere the Quran ostensibly denies any kind of experience or

$5^{2}$ It might be observed that the Arabic term nafs corresponds to the Syriac napšā, a word which the Syriac writers use to expound their doctrine of the sleep of souls. 
life before the resurrection, these two passages state that martyrs are already "living with their Lord". How to interpret the fact that despite being opposed to one another both of these views find a place within the same eschatological discourse?

Once again, a possible answer to this question is found in the Quran's cultural context and in evidence found in Syriac sources. Scholars have noted that in the works of some Syriac authors the same mutually contradictory beliefs co-exist. Indeed, despite their acceptance of the soul's dormant state, Syriac writers often confirmed the common belief that martyrs receive immediate reward and that they could intercede on behalf of the living, particularly at holy places. For instance, in the Hymns on paradise Ephrem affirms that "blessed indeed is that person on whose behalf * they ${ }^{53}$ have interceded before the Good One" (6:19). ${ }^{54}$ Elsewhere in the Hymns, Ephrem repeats this concept: "may all the children of light ${ }^{55}$ * make supplication for me there" $(7: 25) \cdot{ }^{56}$ Of course, the idea that martyrs can intercede with their prayers suggests their actual activity and thus rather contradicts the doctrine of the soul's sleep that Ephrem teaches elsewhere. Nevertheless, the poet does not make any attempt to reconcile the two views.

Ephrem's case is not an exception among the Syriac authors. Jacob of Serugh's homilies also refer both to beliefs about the sleep of souls and to the ability of martyrs to intercede with God. ${ }^{57}$ Commenting on Jacob, Guinan remarks that "the intercession and the protection of martyrs and saints presents difficulties in light of the clear teaching on the sleep of all until the resurrection". ${ }^{8}$ In fact, he observes that within the eschatological framework emerging from Jacob's works the specific case of martyrs appears to be highly confused, for in some passages Jacob "seems to say that the faithful and the persecuted will be glorious with their crowns only in the last day".59 This last sentence suggests that martyrs will enter paradise only after the Last Judgment and that in the meantime their souls will be sleeping in Sheol, as such, they could not intercede before their resurrection.

53 Ephrem is here talking about the just, presumably martyrs, who are already in paradise.

54 Ephrem, Hymns on paradise 115.

55 Elsewhere in the seventh hymn (v. 19), Ephrem refers to "the seven sons of the light". As observed by Brock, this is a reference to the seven Maccabean martyrs of 2 Macc. 7 . Ibid., 193 .

$56 \quad$ Ibid., 128.

57 See Guinan, Where are the dead?

58 Ibid., 548.

59 Ibid. 
The case of Narsai represents another example worthy of mention. In Homily 25, this East Syrian poet infers that through their prayers martyrs guarantee the safety of others and deliver them from tribulations. ${ }^{60}$ However, once again, this idea is not fully consistent with the eschatological doctrines that Narsai embraces elsewhere in his work. The difficulty of reconciling these two views eventually led to a dispute among scholars about the correct understanding of Narsai's eschatological teaching. ${ }^{61} \mathrm{~A}$ final example to be mentioned is that of Babai, in whose theological system, as was seen above, the soul's postmortem inactivity occupies a central place. Nevertheless, concerning the martyrdom of the monk George, Babai too refers to the belief in the martyrs' power of intercession:

$[\mathrm{M}]$ ay the prayers of this crowned martyr be for all those who continually live in truth and follow in the footsteps of his orthodoxy [...] and [may his prayers] particularly be for this monastic congregation, in which he grew up spiritually and from which he was led to the victory of his marvelous martyrdom. ${ }^{62}$

That martyrs enjoyed the exceptional privilege of proceeding to immediate post-mortem reward was a fairly widespread idea during Late Antiquity. This view, suggested several times in the New Testament, was given definitive shape by Tertullian ${ }^{63}$ and maintained by many late antique Christian writers. Because of their privileged position close to God, martyrs were credited with the power to intercede with their prayers on behalf of the living. ${ }^{64}$ This belief was shared also by Syriac Christians, although the idea of the martyrs' post-mortem activity was at odds with the doctrine of the sleep of souls. ${ }^{65}$ However, the Syriac theologians apparently accepted and simultaneously referred to both creeds without trying to harmonize them. As Daley correctly observes in the case of Narsai, "it would be artificial to attempt to reconcile these two convictions: they are simply further evidence of the many elements-philosophical,

\footnotetext{
6o Narsai, Homélie sur les martyrs.

61 See Khouri-Sarkis, Sommeil; Krüger, Sommeil 193-6.

62 Quoted by Reinink in: Babai the Great's Life of George 177.

63 Tertullian, De anima 55-8.

64 See Daley, Hope; Reynolds, Qur'ān 161-7.

65 The difficulty of reconciling the two views must also have been felt during Late Antiquity. Indeed, the sixth century presbyter of Constantinople Eustratios wrote a treatise against "those who say that the souls of the dead are not active", with the aim of demonstrating the post-mortem activity of the souls of the departed saints. See Constas, To sleep 109-11; Daley, Hope 200.
} 
biblical, liturgical and folkloric - that together shape ancient eschatology".66 Such a mélange of diverse, if not mutually contradictory, views is to be related to the absence of an officially canonized doctrine about the post-mortem fate of the dead during Late Antiquity. More than representing a coherent system, the picture that emerges from the Syriac authors' teachings about the interim state of the dead seems to reflect the fluidity and theological difficulties of their cultural environment.

Once adopted, this perspective also helps to settle the difficulties that the specific case of martyrs raises within the framework of the Quranic view of the intermediate state. Like the Syriac writers, the Quran does not attempt to reconcile the belief in the privileged fate of martyrs with the idea of the dead's inactivity that it professes elsewhere. Similar observations have already been made by Tor Andrae, who is particularly keen to stress the communion of views between the Quran and the East Syrian Church, "[qui] faisait une exception pour les martyrs et leur assurait après la mort un autre sort que celui du commun des mortels". ${ }^{67}$ Andrae directs attention to a proclamation by Mar Ishai (sixth century) that, as he correctly observes, closely recalls that found in Q 3:169 (i.e., martyrs "are living with their Lord"): "People believed that they are dead. But their death killed their sin and they are living in the presence of God". ${ }^{68}$ According to Andrae, the striking parallel between these two assertions suggests that the author of Q 3:169 (Muhammad, in his view), "ostensibly uses a common form of the Syriac homiletic vocabulary". ${ }^{99}$ Reynolds espouses Andrae's point, adding that Ishai's view of martyrdom as an act of expiation for sins ("their death killed their sin"), is recalled in turn by the statement in Q 3:157 "if you are slain or die in God's way, forgiveness and mercy from God are a better thing than that which you amass".70

Previous scholars have convincingly shown the extent to which theological doctrines professed by the Quran and by the Syriac authors about the privileged fate reserved to martyrs overlap. ${ }^{71}$ However, one further aspect needs to be added to the discussion. It can be observed that, contrary to the beliefs expressed by Syriac Christians, the Quran lacks any meaningful reference to the martyrs' ability to intercede with God in favor of the living. The absence of

\footnotetext{
66 Ibid., 174.

67 Andrae, Origines 168.

68 Ibid., Quoted also by Reynolds, Qur'ān 166.

69 Andrae, Origines 168.

70 Reynolds, Qur'ān 166.

71 Refoule quite convincingly argues that at the time of Origen the belief in the martyrs' special status was probably also shared by Arab Christians. Refoulé, Immortalité $36-7$.
} 
this specific element does not seem fortuitous, but rather agrees with another aspect of Quranic theology, namely, its denial of the possibility of intercession $\left(\operatorname{shafa}^{\prime} a\right)$. This denial occurs in the framework of the Quran's polemic against the association of God with secondary divinities. The mushrikün are often accused of expecting their deities to intercede with God on their behalf. For instance, Q 10:8 states: "They serve, apart from God, what hurts them not neither profits them, and they say, 'These are our intercessors with God'". As Hawting observes, "the reliance which the mushrikun place on these mediators will in fact lead to their damnation because by relying on them they are failing to be true monotheists". ${ }^{72}$ The Quran opposes this belief by denying the power of intercession with which the secondary divinities are credited $(Q$ 32:4; 40:18), professing instead that no intercession is possible without God's permission ( $Q$ 2:225; 10:3; 19:87; 34:23). Sinners will be mocked because of the absence on the Day of Judgment of those whom they expected to intercede on their behalf: "We do not see with you your intercessors, those you asserted to be associates in you" (Q 6:94. Cf. 18:52; 41:47).

In addition to denying the possibility of intercession on the Day of Judgment (that is, without God's permission), it appears that the Quran dismisses intercession in the present life: "Say: 'What think you? That you call upon apart from God-if God desires affliction for me, shall they remove His affliction? Or if He desires mercy for me, shall they withhold His mercy?' " (Q 39:38). The idea expressed in this verse is particularly interesting in the context of the present discussion, because it is manifestly discordant with the hope of benefiting from the martyrs' intercession professed by Syriac Christians. In light of these observations, it is not surprising that, while agreeing with the Syriac theologians in recognizing a privileged eschatological position to "those who were slain in God's way", the Quran distances itself from the belief in their ability to intercede in favor of the living. It seems likely that in so doing the Quran aims to correct what it considers a doctrinal mistake made by Christians, as from its perspective conferring on martyrs an attribute belonging solely to God (Q 39:44) jars with strict monotheism. This case study could be taken as a good example of how the Quran positions itself vis-à-vis the doctrines professed by the other communities of its historical context: the author(s) of the Quran did not simply share the Christians' beliefs about martyrs but also reacted against them, in accordance with their own theological ideas.

72 Hawting, Idolatry 477. See also Crone, Religion $15^{8-9 .}$ 


\section{Concluding Remarks}

In conclusion, the Quran's conceptions about the interim state of the dead are consistent with beliefs and doctrines largely widespread among the religious communities that formed its cultural environment. Unsurprisingly, the Quran reflects the theological views, the creeds, and the related literary themes, motifs and tropes typical of its late antique context. At the same time, it is important to stress that this material is inserted into a framework that is developing its own particular religious message. The appreciation of the relationship between the Quran and its cultural environment should not lead one to underestimate the originality of a text that possesses a unique character.

For instance, it is worth remarking that the Quran demonstrates but little interest in the moment separating death from the final events, which it only sporadically alludes to. Indeed, this attitude differs significantly from the theological interests developed by Syriac authors, who discuss in detail the condition of the soul in Sheol. The Quran's counter-current tendency on this point reflects the specific character of a work whose major aim is not to establish a doctrinal or systematic theology, but rather to exhort its audience to repent and believe in its message. It is quite evident what the rhetorical interest is that leads the Quran to focus on the description of the post-mortem fate of humanity in heaven and hell, rather than in the intermediate state. ${ }^{73}$ The rhetorical purpose is also strong in Q 23:99-100, whose point is not to provide a picture of the dead's condition beyond the barzakh, but to warn that repentance will not be possible once death has come. In a similar way, the recurring allusions to the motif of post-mortem oblivion are never meant to explain the intermediate state, but rather seem to reflect general concepts about the soul in relation to its final reunion with the body.

Finally, it can be observed that the marginal role the Quran assigns to the pre-resurrection condition of the dead is consistent with its own view of the history of human salvation. Beginning with the fall of Adam and destined to end on the Day of Judgment, this sacred history is the recounting of events in motion, presented as a series of recurring events and repetitive situations within a continuous overlap between present and past, a history that has its raison d'être only in the accomplishment of God's promise. The result is the creation of a kind of "eternal now", 74 where the final reward is not located in a

73 Here I follow an observation made by Gabriel Reynolds during a private conversation (April 16, 2012).

74 The (a-)temporal dimension of the "eternal now" also characterizes the work of Ephrem; on this point see Brock, The luminous eye 29-30. 
far future, but in the moment that immediately follows the present. The proximity of the reward is stressed by the fact that, as Christian Lange observes, descriptions of paradise in the Quran are generally not marked as referring to future events, but rather seem to imply a synchronous relationship between this world and the next. ${ }^{75}$ This aspect further explains why so little importance is attributed to the moment between death and resurrection, a moment that cannot play any role in the attainment of individual salvation, as repentance is not possible after death.

\section{Bibliography}

\section{$1 \quad$ Sources}

4 Ezra = The Fourth Book of Ezra, the Latin edition edited from the Mss, ed. Bensly, R.L., Cambridge 1895 .

Augustine: The "De haeresibus of St. Augustine", ed. Müller, L.G. (Patristic Studies 9o), Washington 1956.

Babai the Great: Liber de unione, ed. Vaschalde, A. (Corpus Scriptorum Christianorum Orientalium 79/80, Scriptores Syri 34/35), Leuven 1915.

- Commentary on Evagrius, in Frankenberg, W.: Evagrius Ponticus (Abhandlungen der königlichen Gesellschaft der Wissenschaften zu Göttingen, Phil.-hist. Klasse, Neue Folge 13.2 [1912]), 422-71.

Barsanuphius and John the Prophet: Letters, volume 2, trans. Chryssavgis, J.: The Fathers of the Church: A new translation (Patristic Series 114), Washington, DC 2007.

Cyril of Scythopolis: Vita Sabae, in Schwartz, E. (ed.): The lives of the monks of Palestine, Leipzig 1939, 85-200.

Ephrem: Saint Éphrem. Commentaire de l'Évangile concordant: texte syriaque (Manuscrit Chester Beatty 709), ed. Leloir, L. (Chester Beatty Monographs 8), Dublin 1963.

- Saint Ephrem's commentary on Tatian's Diatessaron: An English translation of Chester Beatty Syriac Ms 709 with introduction and notes, trans. McCarthy, C., Journal of Semitic Studies Supplement 2, Oxford 1993.

—- Des heiligen Ephraem des Syrers Hymnen de Virginitate, ed. Beck, E. (Corpus Scriptorum Christianorum Orientalium 223-4, Scriptores Syri 94-5), Louvain 1962.

- Ephrem the Syrian. Hymns on the nativity, Hymns against Julian, Hymns on Virginity and on the symbols of the Lord, trans. McVey, K.E., New York-Mahwah 1989. - St. Ephrem the Syrian. Selected prose works: Commentary on Genesis, commentary on Exodus, homily on Our Lord, letter to Publius, trans. Mathews, E.G., and Amar, J.P.: The Fathers of the Church: A New Translation 91, Washington D.C. 1994.

75 Lange, Discovery 10. 
: Hymns on paradise, trans. Brock, S., New York 1990.

- Des Heiligen Ephraem des Syrers Hymnen de Paradiso und Contra Julianum, ed.

Beck, E. (Corpus Scriptorum Christianorum Orientalium 174, Scriptores Syri 78), Leuven 1957.

—- Des heiligen Ephraem des Syrers Carmina Nisibena, ed. Beck, E. (Corpus Scriptorum Christianorum Orientalium 218-9, Scriptores Syri 92-3), I, Leuven 1961.

—- Des heiligen Ephraem des Syrers Carmina Nisibena, ed. Beck, E. (Corpus Scriptorum Christianorum Orientalium 240-1, Scriptores Syri 102-3), II, Leuven 1961. Eusebius: Ecclesiastical history, in Schaff, P., and Wace, H. (eds.): Nicene and Post-Nicene Fathers, second series, I, Peabody, MA 1995², 81-386.

Hyppolitus: Against Plato on the cause of the universe, in Roberts, A., and Donaldson, J. (eds): The Ante-Nicene Fathers: The writings of the Fathers down to AD 325, V, Peabody, MA 19952, 221-3.

Histoire nestorienne inédite: Chronique de Séert (Chronicle of Seert), ed. and trans. Scher, A. (Patrologia Orientalis VII.2), Paris $195^{\circ}$.

Howard, G. (trans.): The teaching of Addai, Chico 1981.

Jacob of Serugh: Homiliae selectae Mar-Jacobi Sarugensis, ed. Bedjan, P., Paris 1905.

: Homilies on the Resurrection, trans. Kollamparampil, T., The metrical homilies of Mar Jacob of Sarug 5 (Texts from Christian Late Antiquity 14), Piscataway, N.J. 2008.

: Homilies on Elijah, trans. Kaufman, S.A., The metrical homilies of Mar Jacob of Sarug 9-13 (Texts from Christian Late Antiquity 18), Piscataway, N.J. 2009.

John of Damascus: Liber de haeresibus. Opera polemica, ed. Kotter, B., Die Schriften des Johannes von Damaskus IV, Berlin-New York 1981.

Martínez, F.G. and Tigchelaar, E.J.C. (ed.): The Dead Sea Scrolls study edition, LeidenBoston-Cologne 1997.

Narsai: Homélie sur les martyrs, trans. Krüger, P.: Traduction et commentaire de l'homélie de Narsai sur les martyrs, in Orient Syrien, 3 (1958), 299-316.

— : Narsai doctoris Syri homilice et carmina, ed. Mingana, A., Mosul 1905. : Cinq homélies sur les paraboles évangéliques, ed. Pataq Siman, E., Paris 1984.

: Narsai's metrical homilies on the Nativity, Epiphany, Passion, Resurrection and Ascension, ed. McLeod, F.G. (Patrologia Orientalis 40.1), Turnhout 1979.

Origen: Treatise on the Passover; and, dialogue of Origen with Heraclides and his fellow bishops on the Father, the Son, and the soul, trans. Daly, R.J., New York 1992.

: De principiis, in Roberts, A., and Donaldson, J. (eds.): The Ante-Nicene Fathers: The writings of the Fathers down to AD 325, IV, Peabody, MA 19952, 239-382.

Tertullian: Quinti septimi florentis Tertulliani de anima, ed. Waszink, J.H., Amsterdam 1947.

Timothy I: Timothei Patriarchae I epistulae, ed. Braun, O. (Corpus Scriptorum Christianorum Orientalium 67/75, Scriptores Syri 30/31), Leuven 1914. 
$2 \quad$ Studies

Abdel Haleem, M.: Introduction to the Qur'an, London-New York 2000.

Bell, R.: The origin of Islam in its Christian environment, London 1968.

Braun, O.: Moses Bar Kepha und sein Buch von der Seele, Freiburg 1891.

Brock, S.: The gates/bars of Sheol revisited, in Petersen, W.L., Vos, J.S., and de Jonge, H.J. (eds.): Sayings of Jesus: Canonical and non-canonical. Essays in honour of Tjitze Baarda, Supplements to Novum Testamentum 89, Leiden 1997, 7-24.

: The luminous eye, the spiritual world vision of Saint Ephrem, Kalamazoo, MI 1992.

Buchan, T.: "Blessed is He who has brought Adam from Sheol": Christ's descent to the dead in the theology of Saint Ephrem the Syrian, Piscataway, NJ 2004.

Carra de Vaux, B.: Barzakh, $E I^{2}$, I, 1071-2.

Constas, N.: To sleep, perchance to dream: The middle state of souls in Patristic and Byzantine literature, in Dumbarton Oaks Papers, 55 (2001), 91-124.

Crone, P.: The religion of the Qur'ānic pagans: God and the lesser deities, in Arabica, 57 (2010), 151-200.

Daley, B.: The hope of the early Church: A handbook of Patristic eschatology, New York 1991.

Donner, F.: Muhammad and the believers: At the origins of Islam, Cambridge, MA 2010.

Eklund, R.: Life between death and resurrection according to Islam, Uppsala 1949.

Gavin, F.: The sleep of the soul in the early Syriac church, in JAOS, 40 (1920), 103-20.

Gignoux, P.: Les doctrines eschatologiques de Narsai, in L'Orient Syrien, 11 (1966), 32152, 461-88; 12 (1967), 23-5.

Griffith, S.: The 'Companions of the Cave' in the Sürat al-Kahf and in Syriac Christian tradition, in Reynolds, G.S. (ed.): The Qur'an in its historical context, New York 2007, 109-37.

Guinan, M.D.: Where are the dead? Purgatory and immediate retribution in James of Sarug, in Ortiz de Urbina, I. (ed.): Proceedings of the International Symposium Syriacum - 1972 (Orientalia Christiana Analecta 197), Rome 1974, 541-50.

Hawting, G.: The idea of idolatry and the rise of Islam: From polemic to history, Cambridge 1999.

— Idolatry and Idolaters, $E Q$, II, 475-80.

Idleman Smith, J. and Yazbeck Haddad, Y.: The Islamic understanding of death and resurrection, New York-Oxford $20022^{2}$.

Jeffery, A.: The foreign vocabulary of the Qur'ān, Leiden 1938.

Khouri-Sarkis, G.: Le sommeil des âmes, in Orient Syrien, 3 (1958), 489-94.

Kollamparampil, A.G.: The theme of Sheol in the Syriac liturgy: The path to its reception, in Ephemerides Liturgicae, 113,4-5 (1999), 289-306.

Kreitzer, L.: Luke 16:19-31 and 1 Enoch 22, in Expository Times, 103 (1992), 139-42. 
Krüger, P.: Le sommeil des âmes dans l'oeuvre de Narsai, in L'Orient Syrien, 4 (1959), 193-210.

Lange, Ch.: Barzakh, in $E I^{3}$, s.v.

— The discovery of paradise in Islam. Aanvaarding van het ambt van Hoogleraar in Islam en Arabisch aan de Universiteit Utrecht (2012, april 16), Utrecht 2012.

Lehtipuu, O.: The afterlife imagery in Luke's story of the rich man and Lazarus, LeidenBoston 2007.

Osei-Bonsu, J.: The intermediate state in Luke-Acts, in Irish Biblical Studies, 9 (1987), $115-30$.

O'Shaughnessy, T.: Muhammad's thoughts on death: A thematic study of the Qur'anic data. Leiden 1969.

Refoulé, F.: Immortalité de l'âme et résurrection de la chair, in Revue de l'Histoire des Religions, 163 (1963), 11-52.

Reinink, G.J.: Babai the Great's Life of George and the propagation of doctrine in the late Sasanian empire, in Drijvers, J.W. and Watt, J.W. (eds.): Portraits of spiritual authority: Religious power in early Christianity, Byzantium and the Christian Orient, Leiden 1999, 171-94.

Samellas, A.: Death in the eastern Mediterranean (50-6oo AD): The Christianization of the East. An interpretation, Tübingen 2002.

Teixidor, J.: Le thème de la Descente aux Enfers chez saint Éphrem, in L'Orient Syrien, 6 (1961), 25-40.

Zaki, M.M.: Barzakh, EQ, I, 203-4. 